\title{
Toward a Discourse of Heteronomy
}

\section{Max van Manen}

University of Alberta

The preceding articles in this section were presented at a symposium of the American Education Research Association Annuai Conference (1992). I was asked to respond to these papers and to their focus on "educational discourse and the ways such discourse constructs and reflects notions of self, other, and the profession" (Barritt, AERA Calendar). In my response I addressed this symposium theme of discourse, self, other, and Maxine Greene's concern with public spaces, first in a general way at the hand of some observations from a book by Taylor (1991) The Malaise of Modernity. Next I applied these concerns to the various papers in particular. Here follows the original response text.

Taylor (1991) recently argued that the malaise of modernity, which we experience as loss of meaning, the eclipse of ends in the face of rampant instrumentalism, and the loss of freedom, needs to be explained rather than merely accepted as the unalterable terms of our postmodern reality. I think this request for an explanation is important because many of us are astounded at the speed and the extent with which contemporary educational discourses critical of modernity and advocating deconstructionist and postmodern values have taken over the languages by way of which researchers currently express themselves and their interests.

"What we need to explain," Taylor (1991) says, is something that "is peculiar to our time. It's not just that people sacrifice their love relationships, and the care of their children, to pursue their careers. Something like this has perhaps always existed. The point is that today many people feel called to do this, feel they ought to do this, feel their lives would be somehow wasted or unfulfilled if they didn't do it" (p. 17).

The moral experience of calling or vocation has always expressed a certain relation between personal space and public space. In this relation, the self forms its identity and finds its fulfillment in the service of others. Values that define our public life by definition must somehow be found outside of the self and in recognition of what is other to us.

But if Taylor is right, then we live now in an age where moral experience has collapsed the sphere of the public into an ever decreasing circle of the self. Taylor argues that this preoccupation with self is not 
adequately explained with notions of narcissism or selfishness (people are not less moral), but rather that the postmodern individual is less able and less inclined to recognize sources of meaning, criteria of truth, and standards of value that lie outside the realm of the self and personal identity. His explanation is that there now exists a new kind of morality that is self-referential not only in its form, but also in content.

Earlier moral views were always in touch with some external source whether it be God, our children, the idea of the good, or our sense of communal public. But now the only source we have to connect with is deep within us. For the postmodern modern, being true to myself means being true to my own originality, my own story, and that is something only I can articulate and discover. And in explicating my story I am also defining myself, my self-identity. I am realizing a potentiality that is properly my own.

Underlying this soft relativism of postmoderns is the moral principle that no one has the right to criticize another's values. As Maxine Greene points out, postmodernity celebrates difference, contingency, plurality, while denying sameness, essence, meaning. Even the self is fragmented, indeterminate, incomplete, uncertain. This postmodern image of identity also suggests, of course, a certain notion of society, of how we ought to live together or, rather, not live together. One senses a limited concept of public in all this contemporary discourse.

Etymologically the term public derives from poplicus meaning belonging to the people. But the contemporary significance of others, of intimacy and love relationships is not primarily an expression of the recognition of others, of the public, of what belongs to the people, but rather an expression of the desire of the self to be recognized by others. In contemporary postmodern culture the public sphere is important especially because the social relations of family, work, and community are, in Taylor's words, "the crucibles of inwardly generated identity" ( $p$. 49).

I now see a possible theme in the papers of Greene, Aptekar, and Barritt and Marshall. All these papers operate in the tension between self and other, the subjectification of ordinary life and the objectification of tradition. Things that were once settled by external reality (such as the literature of the profession, the procedures of ethnographic research of children's cultures, the prefigured space of the public) now are denied their authority and referred to our choice. Thus we search for an appropriate rhetoric of the self, the interpretive significance of child in the self, and the source of agency empowering the self in the formation of public space. 
In education too our modern perspective is undeniably self-referential. In other words, ideals of freedom and autonomy center on selves and require that we discover and articulate our own identity and that we respect the identities of other selves. However-and herein lies the problem-this does not mean that on another level the content of our values, truth, and commitments must be self-referential.

And yet this is the trend. Teachers are currently widely encouraged to take an interest in self, authenticity, and in personal autonomy. However, the content of norms and the meanings of pedagogy cannot be found in narrative searches for authenticity and self-fulfillment. The meaning of pedagogy for teachers lies not in personal autonomy, but in heteronomy. The word heteronomy describes something that goes beyond the self-referential principle of autonomy and authenticity.

Moreover, while teachers have been invited to write their personal stories, the voices that are still silent are those of the children. The heteronomy of responsibility lies at the heart of our relation to the children we encounter, teach, or parent. It refers us to the call this other person, this child, makes on our personal responsibility. Aptekar's description of the effect of his newborn child on his sense of responsiveness illustrates this call.

Heteronomy means other and nomo means law. Heteronomy is the other side of autonomy: it means to be claimed by or to be dependent on something that comes from the outside in contrast to autonomy, which means "living by one's own laws." Thus we could speak of the heteronomy of the vocation of teaching or pedagogy.

In a professional field we must explore the many forms of the substitutive heteronomy of responsibility: the responsibility of the ethnographer, the researcher, the administrator, the teacher, the parent. All are called to their ethical encounter with the other. And yet, if Taylor is even partly right, then our postmodern predicament is such that we experience not the other, but especially the self as our moral calling.

Aptekar, Barritt and Marshall, and Greene help us in confronting this struggle or tension between the autonomy and heteronomy, self, and other in our profession.

Aptekar tells about two children who have begun to give interpretive significance to his ethnographic studies of street children: the child in the ethnographer and the child of the ethnographer. The child in the ethnographer is the title of his paper and the dominant theme as he describes his work presently-but the child of the ethnographer arrives as a surprise, and later in the paper and we are left to wonder what this child's role will be. Aptekar describes his fatherhood as it is awakened by this newborn child for whom he has suddenly and so inexplicably 
found himself responsible. I found his description of his reluctant fatherhood quite moving. As readers we feel that Aptekar's interpretations of the nature of street children may undergo yet another transformation once the internal child, the self, has moved over somewhat to make a place for this new child, the other. My question would be this: Is a pedagogical ethnography inspired not only by the child in the ethnographer, but also by the child of the ethnographer possible? And if so, what may a truly pedagogical ethnography of street children look like?

Barritt and Marshall give us a critical and provocative argument about the archaic usage of literature citation in high reputation research journals. Their paper is attractive because it is so refreshing to hear articulated in such eloquent manner what many of us have often thought about but never said aloud. The present usage of literature by the profession is often given to borrowing questionable "respect," acknowledging illegal ownership, claiming dubious patents of ideas, and justifying often irrelevant research practices. Many of us have been irritated by the way academic elites who run the research journals have been able to levy taxations of meaningless citations of literature for our research. A sociology of knowledge underlying these practices might show that many of the creative ideas in educational research are often produced locally and on the margins by the academic peasantry. While the latter must pay their dues in citing the ideas that belong to the elites, the elites seem able to claim ownership and originality of intellectual material that clearly had been sprouted and grown in the small gardens and plots of the academic underclass to begin with. Thus herein lies the great irony that, in order to get published in high reputation journals, one must respectfully quote ideas from those more powerful, while those ideas were one's own to begin with.

We feel indebted to Barritt and Marshall when they say, "We share the frustrations of colleagues who have written us that though they would like to write in a way that reflects their thoughts and actions, they cannot do so if they wish to be published."

Yes, in these lamentations we also hear the tension between self and other, individual, and tradition. The literature is on the one hand a set of rules or an epistemology from which we want to be liberated. But the literature is also a depository formed by the contribution of significant others whose influences not only shaped our beginnings, but also continues to influence us throughout our lives. It is only against the background of the literature that our understandings and our interests make sense. Barritt and Marshall argue that we need to create more dialogical spaces where we can meet each other as equals-not just to be heard and be published, but for the sake of our vocational others, the children who hopefully benefit from our labor. 
Listening to Maxine Green is for me always a humbling experience, somewhat like a literary experience of a novel that transforms us. Afterward I would rather reflect and be quiet than talk and hastily say things I might regret. Yet here I stand: Maxine Greene is urging us to find ways of turning autonomy of local agency into pedagogical heteronomy, responsibility for the other. Maxine Greene argues that particularities such as "the abuse of a child, a situation of homelessness, or an understaffed school ought to call a public into being." She also says that "a public space cannot exist without commitment of participants to reach beyond themselves." She implies that in our age human beings may not necessarily be sensitive to those commitments. But she sees possibilities for diverse human beings to form a public that, in her words, "can be awakened to their being in the world." What reason is there to hope for the improvement of children's lives, the homeless outside this conference hotel, and the disadvantaged children? In some sense all children are disadvantaged in the modern world. What ground is there to hope in a world that seems so fragmented and uncertain, and if at all "committed," to use Maxine Greene's term, then committed to some kind of despair of the self?

I would like to ask Maxine: How do we "strain toward the common?" How do we develop noninstrumental understandings of the inescapable instrumentalities that frame our practices? How do we struggle beyond the postmodern discourses that seem to be caught up in paradoxical instrumentalities of our own lives? Maybe we have invented too many discourses already? If I were a young person attending the hundreds of conference sessions, including this one, espousing modernist promises and postmodern critiques, how would I know that all this esoterica is all about me? All for my benefit?

References

Taylor, C. (1991). The malaise of modernity. Concord, ON: House of Anansi Press. 